\title{
Cisne Negro
}

\section{Black Swan}

\section{Francisco Medina Romero ${ }^{1}$ María Fernanda Lara Martínez ${ }^{1}$ Tania Rodríguez Méndez ${ }^{1}$}

${ }^{1}$ Complejo Hospitalario Universitario de Canarias, Santa Cruz de Tenerife, España

Rev Argent Radiol 2022;85(Suppl S1):S22.

Muchos de los radiofármacos utilizados en medicina nuclear se excretan por vía urinaria, eso mismo ocurre con el 99mTcHMDP en la gammagrafía ósea.

En nuestro paciente, en un estudio para descartar metástasis por un cáncer de próstata, la vejiga y la sonda de la cistostomía suprapúbica llenas de orina ( - Figs. 1, 2), pueden asemejarse al cuerpo y cabeza de un cisne de color negro (- Fig. 3 ).

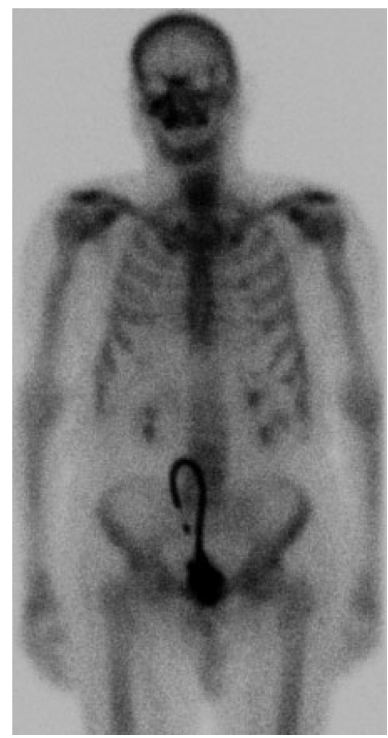

Fig. 1 Gammagrafía ósea en fase tardía en proyección anterior, en la que se observa una vejiga y una sonda de cistostomía suprapúbica llenas de radiofármaco.
Address for correspondence Francisco Medina Romero, Complejo Hospitalario Universitario de Canarias, Santa Cruz de Tenerife, España (e-mail: drfranciscomedina@gmail.com).

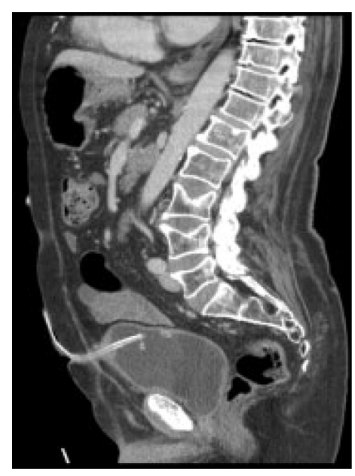

Fig. 2 Imagen de tomografía axial computada en proyección sagital, en la que se observa la cistostomía.

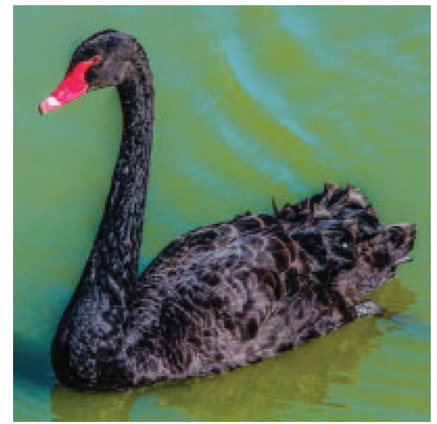

Fig. 3 Cisne negro.

(c) 2018. Asociación Civil Sociedad Argentina de Radiología and Federacion Argentina de Asociaciones de Radiología, Diagnóstico por Imágenes y Terapia Radiante. All rights reserved.

This is an open access article published by Thieme under the terms of the Creative Commons Attribution-NonDerivative-NonCommercial-License, permitting copying and reproduction so long as the original work is given appropriate credit. Contents may not be used for commercial purposes, or adapted, remixed, transformed or built upon. (https://creativecommons.org/ licenses/by-nc-nd/4.0/)

Thieme Revinter Publicações Ltda., Rua do Matoso 170, Rio de Janeiro, RJ, CEP 20270-135, Brazil 